\title{
Analisis Psikometri Aitem Need of Agression Tes EPPS pada Remaja Akhir
}

\section{Psycometric Analysis Need of Agression Item of EPPS Test in Adolescents}

\author{
Elok Fa'iz Fatma El Fahmi ${ }^{1 *}$, Umdatul Khoirot ${ }^{2}$, Fuji Astutik ${ }^{3}$ \\ 1,2,3 Fakultas Psikologi UIN Maulana Malik Ibrahim, Malang
}

Received October 29, 2021| Accepted Desember 03, 2021| Published Desember 15, 2021

\begin{abstract}
Abstrak: Edwards Personal preference Schedule (EPPS) adalah salah satu alat ukur yang cukup popular digunakan dalam dunia psikologi yang digunakan untuk melihat kepribadian individu melalui Teknik non-proyeksi atau inventory. Terdapat 15 kebutuhan (need) pada EPPS, salah satunya adalah need of agression. Pada penelitian ini dilakukan analisis deskriptif terkait analisis psikometri menggunakan model Rasch yang meliputi validitas, reliabilitas, tingkat kesulitan item, dan Differential Item Functioning (DIF). Hasil penelitian ini menyatakan bahwa item-item yang mengukur need of aggression memiliki nilai koefisien validitas dan reliabilitas yang baik. Terdapat satu item yang memiliki tingkat kesulitan tinggi dan satu item yang memiliki tingkat kesulitan rendah. Kemudian terdapat dua item yang terdeteksi bias berdasarkan jenis kelamin.
\end{abstract}

Kata Kunci: Need of Agression; Analisis Psikometri; model Rasch; EPPS; Remaja

Abstract: Edwards Personal Preference Schedule (EPPS) is a measurement tool that is quite popular in psychology, which is used to see individual personalities through non-projection or inventory techniques. There are 15 needs (needs) in the EPPS, one of which is aggression. In this study, a descriptive analysis related to psychometric analysis using the Rasch model was carried out, including validity, reliability, item difficulty level, and Differential Item Functioning (DIF). The results of this study indicate that the items that measure the need for aggression have good validity and reliability coefficients. There is one item with a high difficulty level and one with a low difficulty level. Then two items are detected to be biased by gender.

Keywords: Need of Agression; Psycometric Analysis; Rasch Model; EPPS; Adoloscents

\footnotetext{
1* Corresponding Author: Elok Fa’iz Fatma El Fahmi, email: elokfaiz@uin-malang.ac.id, Fakultas Psikologi UIN Maulana Malik Ibrahim Malang, Jl. Gajayana No. 50, Malang, 65144, Indonesia.
} 


\section{Pendahuluan}

Perkembangan keilmuan di Indonesia pada pada kurun waktu 20 tahun terakhir menjadi semakin pesat. Salah satu bidang keilmuan yang juga ikut berkembang adalah bidang psikologi. Sedikit demi sedikit masyarakat mulai mengenal dan memahami peran psikologi di masyarakat, seperti pentingnya kesehatan mental, penggunaan tes psikologi dalam penelusuran bakat minat siswa di sekolah, rekruitmen dan penempatan jabatan di sebuah perusahaan, dan lain sebagainya. Masyarakat menjadi semakin mengenal tes psikologi sebagai rujukan untuk mengetahui kondisi psikologis individu. Penggunaan tes psikologi tidak hanya terbatas pada bidang klinis maupun industri tapi juga banyak digunakan di bidang pendidikan sebagai alat untuk melihat bakat, minat dan kepribadian siswa maupun mahasiswa. Perkembangan ilmu psikologi yang pesat sangat perlu diimbangi dengan perbaikan kualitas dari suatu alat tes. Salah satu usaha yang dapat dilakukan untuk memperkaya tes psikologi adalah dengan melakukan adaptasi alat tes dimana peneliti ataupun praktisi harus menyesuaikan alat tes tersebut dengan kondisi yang ada di Indonesia (Adisubroto, Hadipranata, \& Sudardjo, 1980). Cronbach (1990) mengungkapkan bahwa aspek penting dalam adaptasi maupun pengembangan alat tes adalah menguji validitas dan reliabilitasnya karena melalui uji psikometri tersebut kita dapat menguatkan interpretasi skor dari suatu alat tes.

Validitas dan reliabilitas tes selalu menjadi permasalahan utama ketika seorang peneliti akan melakukan pengukuran psikologi. Hal ini disebabkan karena kesesuaian dan ketepatan suatu alat tes dalam mengukur konstruk yang diukur sangat dipengaruhi oleh tinggi dan rendahnya uji validitas maupun reliabilitas alat tes yang digunakan (Suryabrata dalam Adisubroto, Hadipranata, \& Sudardjo, 1980). Jika menilik dari definisinya, Azwar (2008) mengungkapkan validitas adalah ketepatan dan kecermatan alat ukur dalam menjalankan fungsinya sebagai alat ukur, yang menunjukkan sejauh mana alat ukur tersebut dapat mengukur atribut yang seharusnya diukur, sehingga dapat menghasilkan data yang valid untuk satu tujuan ukur. Sedangkan reliabilitas dikaitkan dengan konsistensi atau keterpercayaan dari suatu alat ukur, yang mengandung makna kecermatan pengukuran.

Salah satu alat ukur yang cukup popular dalam dunia psikologi adalah Edwards Personal preference Schedule (EPPS) yang digunakan untuk melihat kepribadian individu melalui teknik nonproyeksi atau inventory. EPPS disusun oleh Allen L Edward berdasarkan dari manifestasi kebutuhan yang dikembangkan oleh H. A. Murray (Edward, 1959; Diahsari, 2016). Terdapat 15 kebutuhan (need) yang diberi nama dengan singkatan yang khas dan tidak ada perubahan sampai ssekarang yaitu: need of Achievement, need of Deference, need of Order, need of Exhibition, need of Autonomy, need of Affiliation, need of Intraception, need of Succorance, need of Dominance, need of Abasement, need of Nurturance, need of Change, need of Endurance, need of Heterosexuality dan need of Aggression (Diahsari, 2016; Faizah, 2008; Anastasi \& Urbina, 2007; Gregory, 2010). Tes EPPS terdiri dari 225 item dimana masing-masing item terdapat dua pernyataan yang meminta subjek untuk memilih satu pernyataan yang paling sesuai.

Melihat perjalanannya, tes EPPS dikembangkan pada tahun 1950an dan belum pernah mengalami proses revisi sejak diadaptasi di Indonesia pada tahun 1989. Padahal tes EPPS menjadi salah satu pilihan bagi para psikolog maupun akademisi ketika ingin mengungkap kepribadian 
individu melalui teknik non proyeksi. EPPS banyak digunakan di sekolah-sekolah, kedinasan, dan boarding school karena dianggap dapat mengungkap kepribadian seseorang secara mendalam, serta menyajikan pengecekan konsistensi sehingga hasilnya dapat terpercaya (Rosadi, Widyastuti, \& Rifdah, 2018). Berdasarkan hasil uji validitas dan reliabilitas yang telah dilakukan menunjukkan bahwa tes EPPS masih dikatakan valid dan reliabel (Ghei, 1963; Thomas \& Bouchard, 1968; Adisubroto, Hadipranata, \& Sudardjo, 1980). Hasil tersebut berbeda dengan penelitian yang dilakukan oleh Piedmont, McCrae, \& Costa (1992) dan Suhendri \& Rahmawati (2014) yang menunjukkan bahwa koefisien validitas dan daya diskriminan pada tes EPPS tergolong rendah. Penelitian Siregar (2021) pada item heteroseksualitas dengan melakukan uji validitas berdasar struktur internal juga menunjukkan bahwa terdapat satu item yang tidak memenuhi kriteria model pengukuran ideal, dengan hasil uji validitas menunjukkan skor yang rendah

Tidak banyak penelitian yang dilakukan untuk menguji validitas dan reliabilitas EPPS, padahal penting sekali melihat properti psikometri suatu alat tes secara berkala, karena pasti akan ada perubahan subjek maupun kondisi lingkungan penelitian. Penelitian yang dilakukan oleh Kaplan \& Saccuzzo (2005) bahwa validitas dan reliabilitas EPPS yang diukur pada tahun 1992 dan 2005 ini secara keseluruhan adalah sebesar 0,60 - 0,87, hasil kajian pengukuran validitas dan reliabilitas ini tergolong baik. Penelitian terbaru telah dilakukan oleh Siregar (2021) untuk melihat validitas dan reliabilitas, namun hanya sebatas item heteroseksualitas, sehingga sangat perlu pengkajian lebih pada item-item yang lain. Pada penelitian ini, peneliti fokus pada item need of agression. Berdasarkan penelitian yang dilakukan oleh Pratomo (2005) menunjukkan bahwa need of aggression memiliki rata-rata nilai social desirability yang tergolong rendah, yang menunjukkan kecenderungan kurang di respon oleh subjek berdasarkan pertimbangan social desirability. Kemungkinan hal ini terjadi karena budaya Indonesia (terutama jawa) untuk dapat mencerminkan pribadi yang santun, rendah diri, memiliki tutur kata yang halus, dan mengutamakan terpeliharanya penampilan sosial yang harmonis melalui tata krama penghormatan (Soehardi, 2002), sehingga kemungkinan dapat menyebabkan item-item pada need of aggression tidak dapat mengukur dengan baik.

Berdasarkan definisinya, perilaku agresif diartikan sebagai perilaku yang membahayakan oranglain, yang menimbulkan akibat negatif diakibatkan oleh kemarahan (Rozenblatt dalam Hayani \& Wulandari, 2017). Perilaku agresif yang ditunjukkan oleh individu biasanya akan didahului oleh niat, dorongan dan atribusi, dimana hal ini berkaitan dengan kebutuhan atau dorongan individu untuk melakukan tindakan agresif maupun keyakinan individu berdasarkan suatu kejadian sosial sehingga dapat mendorong keputusan dan reaksi yang diberikan dalam suatu situasi sosial (Crick \& Dodge, 1994; Coccaro, 2003). Need menjadi konstruk yang mengorganisir proses persepsi individu, berfikir dan bertindak dalam rangka mengubah kondisi (Yudiati \& Rahayu, 2018). Berdasarkan need yang dijelaskan di EPPS, need of aggession merujuk pada kebutuhan untuk menyerang pandangan orang lain, mengatakan apa yang dipikirkan, mengkritik secara terbuka, mengolok-olok, mengatakan ketidaksetujuan, balas dendam, menyalahkan, dan membaca berita kekerasan (Faizah, 2008; Diahsari, 2016).

Psikoislamika: Jurnal Psikologi dan Psikologi Islam 
Dwiyono (2008) mengungkapkan bahwa laki-laki cenderung menunjukkan perilaku agresif dibandingkan dengan perempuan. Pertanyaan yang muncul adalah apakah ada perbedaan agresivitas antara laki-laki dan perempuan yang diungkap dalam EPPS sebagaimana item heteroseksual yang di ungkap dalam penelitian yang dilakukan oleh Siregar (2021). Berdasarkan penelitian Rosadi, Widyastuti, \& Rifdah (2018) menunjukkan penurunan skor percentil laki-laki dan perempuan, salah satunya pada need of aggression. Norma laki-laki menunjukkan adanya penurunan, dan tidak terjadi perbedaan pada norma perempuan. Melihat perubahan persentil dan norma yang tersebut, perlu juga dilakukan analisis terlebih dahulu terkait kualitas dan keberfungsian item, sehingga dapat meminimalkan social desirability pada tes kepribadian (Corah, et al., 1958). Pada penelitian ini, peneliti menguji validitas, reliabilitas, dan keberfungsian item need of aggression menggunakan analisis model Rasch.

\section{Metode}

Metode penelitian yang digunakan adalah kuantitatif deskriptif, dimana analisis data yang dilakukan yaitu analisis psikometri item need of aggression pada tes EPPS menggunakan model Rasch. Analisis yang dilakukan dengan menggunakan model Rasch adalah menguji validitas, reliabilitas, dan Differential Item Functioning (DIF) pada alat tes. DIF mendiskripsikan kemampuan item memberikan hasil berbeda pada dua kelompok atau lebih yang memiliki kemampuan sama (Osterlind, 2010). Pada model Rasch, untuk menunjukkan adanya bias dalam item dapat dilihat melalui keberfungsian item (DIF), langkah ini diperlukan karena adanya item yang bias dapat mengganggu validitas skor pengukuran yang didapat. Analisis DIF pada penelitian ini dilakukan berdasarkan jenis kelamin. Penelitian ini menggunakan remaja akhir sebagai subjek, batasan usia untuk remaja akhir menurut Berk (2007) adalah 16-18 tahun. Subjek remaja akhir pada penelitian ini adalah calon mahasiswa salah satu Universitas di Kota Malang yang mengisi tes EPPS. Sampel yang digunakan adalah sejumlah 100 orang yang terdiri dari 50 orang berjenis kelamin perempuan dan 50 orang berjenis kelamin laki-laki. Analisis psikometri pada penelitian ini dilakukan dengan bantuan software Winsteps Version 3.73.

\section{Hasil}

Berdasarkan analisis menggunakan bantuan software Winsteps Version 3.73, diperoleh hasil nilai reliabilitas, validitas, item measure, dan DIF. Berikut adalah penjelasan masing-masing analisisnya.

\section{Reliabilitas}

Tabel 1.

Realibilitas

\begin{tabular}{ccccc} 
& $\begin{array}{c}\text { Rata-rata } \\
\text { SD }\end{array}$ & Separation & Reliabilitas & Alpha Cronbach \\
\hline Person & $\begin{array}{cccc}\text {-1.06 } \\
(0,89)\end{array}$ & 1,43 & 0,67 & 0,71 \\
\hline Item & 0,00 & 3,59 & 0,93 & \\
& $(1,00)$ & & & \\
\hline
\end{tabular}


Terlihat pada Tabel 1, nilai rata-rata pada subjek -1,06. Nilai rata-rata di bawah 0 menunjukkan bahwa subjek cenderung tidak setuju terhadap item need of agression pada tes EPPS. Nilai Alpha Cronbach 0,71 menunjukkan bahwa reliabilitas secara umum sudah baik, reliabilitas pada subjek dan item menunjukkan bahwa konsistensi jawaban subjek dan kualitas item dalam tes baik. Menentukan kualitas item dan subjek juga dapat dilihat dari nilai separation, semakin besar nilai nya maka dapat mengidentifikasi kelompok subjek dan item.

Tabel 2.

Rating Scale Instrument Quality Criteria

\begin{tabular}{|c|c|c|c|c|c|}
\hline Criterion & Poor & Fair & Good & $\begin{array}{l}\text { Very } \\
\text { Good }\end{array}$ & Excellent \\
\hline Targeting* & $\begin{array}{l}>2 \\
\text { errors }\end{array}$ & $\begin{array}{l}1-2 \\
\text { errors }\end{array}$ & $\begin{array}{l}<1 \\
\text { error }\end{array}$ & $<.5$ error & $<.25$ error \\
\hline $\begin{array}{l}\text { Item Model Fit Mean-Square Range } \\
\text { Extremes }\end{array}$ & $\begin{array}{l}<.33-> \\
3.0\end{array}$ & $.34-2.9$ & $.5-2.0$ & $.71-1.4$ & $.77-1.3$ \\
\hline $\begin{array}{l}\text { Person and Item Measurement } \\
\text { Reliability }\end{array}$ & $<.67$ & $-67-.80$ & $.81-.90$ & $.91-.94$ & $>.94$ \\
\hline Person and Item Strata Separated & 2 or less & $2-3$ & $3-4$ & $4-5$ & $>5$ \\
\hline $\begin{array}{l}\text { Ceiling Effect: \% maximum extreme } \\
\text { scores }\end{array}$ & $>5 \%$ & $2-5 \%$ & $1-2 \%$ & $.5-1 \%$ & $<.5 \%$ \\
\hline $\begin{array}{l}\text { Floor Effect: \% minimum extreme } \\
\text { scores }\end{array}$ & $>5 \%$ & $2-5 \%$ & $1-2 \%$ & $.5-1 \%$ & $<.5 \%$ \\
\hline $\begin{array}{l}\text { Variance in data explained by } \\
\text { measures** }\end{array}$ & ?? & ?? & ?? & ?? & ?? \\
\hline $\begin{array}{l}\text { Unexplained variance in contrasts } 1-5 \text { of } \\
\text { PCA of residuals }\end{array}$ & $>15 \%$ & $10-15 \%$ & $5-10 \%$ & $3-5 \%$ & $<3 \%$ \\
\hline
\end{tabular}

Berdasarkan kriteria nilai separation subjek dan item menurut Fisher Jr. (2007) yang terlihat pada Tabel 2, nilai separation subjek yang terlihat pada tabel 1 termasuk kriteria yang rendah, dan separation item termasuk kriteria yang bagus.

Tabel 3.

Item Measure

\begin{tabular}{ccc}
\hline Total Score & Measure & Item \\
\hline 6 & 2,02 & $I 13$ \\
\hline 7 & 1,85 & $I 10$ \\
\hline 13 & 1,11 & 125 \\
\hline 15 & 0,92 & 13 \\
\hline 15 & 0,92 & $I 16$ \\
\hline 16 & 0,84 & 124 \\
\hline 17 & 0,76 & 126 \\
\hline 18 & 0,68 & $I 18$ \\
\hline 20 & 0,54 & 19 \\
\hline 22 & 0,40 & 121 \\
\hline 23 & 0,34 & 12 \\
\hline
\end{tabular}

Psikoislamika: Jurnal Psikologi dan Psikologi Islam 


\begin{tabular}{ccc}
\hline Total Score & Measure & Item \\
\hline 24 & 0,27 & 17 \\
\hline 25 & 0,21 & 18 \\
\hline 25 & 0,21 & 111 \\
\hline 25 & 0,21 & 112 \\
\hline 26 & 0,15 & 120 \\
\hline 27 & 0,09 & 123 \\
\hline 31 & $-0,13$ & 127 \\
\hline 38 & $-0,48$ & 122 \\
\hline 43 & $-0,72$ & 16 \\
\hline 45 & $-0,82$ & 11 \\
\hline 47 & $-0,91$ & 117 \\
\hline 48 & $-0,96$ & 115 \\
\hline 51 & $-1,10$ & 15 \\
\hline 58 & $-1,43$ & 128 \\
\hline 59 & $-1,48$ & 14 \\
\hline 61 & $-1,57$ & $I 14$ \\
\hline 68 & $-1,93$ & $I 19$ \\
\hline
\end{tabular}

Dilihat dari nilai item measure pada Tabel 3, Item yang paling sulit disetujui oleh subjek yakni item 13 dengan disetujui sebanyak 6 subjek, sedangkan item yang paling mudah disetujui yakni item 19 dengan disetujui sebanyak 68 orang. Berdasarkan data tersebut yang dimaksud dengan item yang tidak disetujui adalah subjek memilih pilihan tidak setuju atau tidak sesuai dengan dirinya.

\section{Validitas}

Tabel 4.

Infit Outfit Order

\begin{tabular}{ccccc}
\hline & Infit & \multicolumn{2}{c}{ Outfit } \\
\hline & MNSQ & ZSTD & MNSQ & ZSTD \\
\hline Person & 1,00 & 0,1 & 0,96 & 0,0 \\
\hline Item & 1,00 & 0,2 & 0,96 & 0,0 \\
\hline
\end{tabular}

Kriteria infit outfit berdasarkan nilai MNSO yakni rentang 0,5 - 1,50 sedangkan untuk nilai ZSTD rentang -2,0 - 2,0 untuk dapat dikatakan bahwa model ini dapat dianalisis menggunakan model Rasch. Terlihat pada Tabel 3, nilai MNSO dan ZSTD untuk subjek dan item memenuhi kriteria, sehingga model ini dapat dianalisis menggunakan model Rasch. nilai MNSO dan ZSTD masing-masing item dapat dilihat pada gambar di bawah ini. 


\section{Gambar 2.}

Tingkat Kesesuaian Aitem

ITEM STATISTICS: MISFIT ORDER

\begin{tabular}{|c|c|c|c|c|c|c|c|c|c|c|c|c|c|}
\hline ENTRY & TOTAL & TOTAL & & MODEL | & & FIT & OUT & $=I T$ & |PT-ME, & SURE & | EXACT & MATCH| & \\
\hline UMBER & SCORE & COUNT & MEASURE & S.E. I & |MNSQ & ZSTDI & |MNSQ & ZSTD| & | CORR. & EXP. I & OBS\% & EXP\% | & ITEM \\
\hline 23 & 27 & 100 & .09 & .24 & | . .98 & $-.1 \mid$ & |1.31 & $1.6 \mid$ & A. .33 & $.34 \mid$ & 73.0 & 74.7| & I23 \\
\hline 11 & 25 & 100 & .21 & .25 & 1.13 & 1.1 & 1.28 & 1.4 & B . .18 & .33 & 75.0 & 76.4 & I11 \\
\hline 4 & 59 & 100 & -1.48 & .22 & 1.24 & $2.8 \mid$ & 1.28 & $2.3 \mid$ & |C .12 & $.37 \mid$ & 56.0 & $67.6 \mid$ & I4 \\
\hline 6 & 43 & 100 & -.72 & .22 & |1.09 & 1.2 & |1.19 & $1.7 \mid$ & |D .26 & .37| & 63.0 & 66.2 & I6 \\
\hline 15 & 48 & 100 & -.96 & .22 & |1.12 & $1.7 \mid$ & | 1.17 & $1.6 \mid$ & |E .24 & .37| & 59.0 & $65.7 \mid$ & I15 \\
\hline 14 & 61 & 100 & -1.57 & .22 & 1.14 & $1.6 \mid$ & 1.14 & $1.1 \mid$ & F. .23 & $.37 \mid$ & 58.0 & $68.3 \mid$ & I14 \\
\hline 8 & 25 & 100 & .21 & .25 & 1.07 & .6 & 1.12 & $.7 \mid$ & G . .25 & $.33 \mid$ & 77.0 & 76.4 & I8 \\
\hline 10 & 7 & 100 & 1.85 & .40 & |1.02 & .21 & |1.12 & .4| & |H.16 & $.21 \mid$ & 93.0 & 93.0 & I10 \\
\hline 27 & 31 & 100 & -.13 & $.23 \mid$ & 1.02 & .31 & 1.10 & $.7 \mid$ & |I .31 & $.35 \mid$ & 73.0 & 71.5 & I 27 \\
\hline 19 & 68 & 100 & -1.93 & $.23 \mid$ & 1.08 & .81 & 1.08 & $.6 \mid$ & | J & $.36 \mid$ & 66.0 & $71.9 \mid$ & I19 \\
\hline 24 & 16 & 100 & .84 & .29 & 1.03 & .2 & 1.06 & .31 & |K. .26 & .29 & 83.0 & 84.5 & I24 \\
\hline 1 & 45 & 100 & -.82 & .22 & |1.04 & .6 & |1.01 & .1| & |L . .34 & $.37 \mid$ & 59.0 & $65.9 \mid$ & I1 \\
\hline 5 & 51 & 100 & -1.10 & .22 & 1.03 & $.4 \mid$ & | .99 & $.0 \mid$ & |M.36 & $.38 \mid$ & 64.0 & $65.8 \mid$ & I5 \\
\hline 26 & 17 & 100 & .76 & .28 & 1.00 & |1 & 1.02 & $.2 \mid$ & |N.29 & .29| & 82.0 & $83.6 \mid$ & I26 \\
\hline 28 & 58 & 100 & -1.43 & .22 & 1.02 & .2 & .97 & -.21 & n . .37 & $.37 \mid$ & 63.0 & $67.3 \mid$ & I 28 \\
\hline 9 & 20 & 100 & .54 & .26 & |.98 & -.1 & .83 & -.6 & $1 \mathrm{~m} .35$ & .31 & 81.0 & $80.9 \mid$ & I9 \\
\hline 17 & 47 & 100 & -.91 & .22 & .97 & $-.3 \mid$ & .93 & $-.7 \mid$ & 11.41 & .37| & 62.0 & $65.6 \mid$ & I17 \\
\hline 3 & 15 & 100 & .92 & .29 & .97 & $-.1 \mid$ & .72 & $-.9 \mid$ & |k.36 & .28 & 85.0 & $85.4 \mid$ & I3 \\
\hline 22 & 38 & 100 & -.48 & .22 & .95 & $-.5 \mid$ & .88 & $-1.0 \mid$ & |j. .43 & .36 & 63.0 & $67.9 \mid$ & I22 \\
\hline 12 & 25 & 100 & .21 & .25 & .94 & -.5 & .81 & -1.0 & |i . .42 & .33 & 77.0 & 76.4 & I12 \\
\hline 2 & 23 & 100 & .34 & $.25 \mid$ & .94 & $-.5 \mid$ & .81 & $-.9 \mid$ & |h .41 & .32 & 79.0 & 78.21 & I2 \\
\hline 16 & 15 & 100 & .92 & .29| & .93 & $-.3 \mid$ & .83 & $-.5 \mid$ & lg. .35 & $.28 \mid$ & 87.0 & 85.4 & I16 \\
\hline 7 & 24 & 100 & .27 & .25 & .92 & -.6 & .89 & $-.5 \mid$ & |f . .41 & .33| & 80.0 & $77.3 \mid$ & I7 \\
\hline 13 & 6 & 100 & 2.02 & $.43 \mid$ & .90 & -.2 & .48 & $-1.0 \mid$ & le .36 & .20 & 94.0 & 94.0 & I13 \\
\hline 20 & 26 & 100 & .15 & .24 & .89 & -.9 & .75 & $-1.4 \mid$ & |d .47 & .33| & 76.0 & $75.5 \mid$ & I 20 \\
\hline 18 & 18 & 100 & .68 & .27 & .87 & $-.7 \mid$ & .70 & -1.2 & |c .46 & $.30 \mid$ & 83.0 & $82.7 \mid$ & I18 \\
\hline 21 & 22 & 100 & .40 & .26 & .82 & -1.3 & .67 & -1.6 & |b .52 & .32 & 81.0 & 79.1 & I21 \\
\hline 25 & 13 & 100 & 1.11 & $.31 \mid$ & .80 & -.9 & .71 & $-.8 \mid$ & |a .47 & $.27 \mid$ & 89.0 & 87.21 & I 25 \\
\hline MEAN & 31.2 & 100.0 & .00 & .26 & 1.00 & .21 & .96 & $.00 \mid$ & & & 74.3 & 76.2 & \\
\hline S.D. & 17.1 & .0 & 1.00 & $.05 \mid$ & |. .10 & .9 & .21 & $1.0 \mid$ & & & 11.0 & 8.4 & \\
\hline
\end{tabular}

Suatu item diterima oleh subjek atau tidak dapat dilihat melalui nilai MNSO, dengan menggunakan kriteria yang sudah dijelaskan di atas. Terlihat pada Gambar 2, nilai MNSO untuk item 1 hingga item 28 tergolong dikriteria yang ditentukan. Ini berarti item-item need of agression pada tes EPPS dapat diterima oleh subjek. Sedangkan untuk melihat kualitas item dapat dilihat melalui nilai ZSTD dengan menggunakan kriteria yang sudah dijelaskan di atas. Pada Gambar 2, terilihat bahwa nilai ZSTD masih termasuk dalam kategori yang sudah ditentukan. Sehingga dapat dinyatakan bahwa itemitem need of agression di tes EPPS termasuk dalam kategori item yang baik. Berdasarkan hasil di atas, dapat disimpulkan bahwa validitas item need of agression pada tes EPPS terpenuhi.

\section{Differential Item Functioning (DIF)}

Pada penelitian ini DIF dilakukan untuk mendeteksi bias berdasarkan jenis kelamin, hasilnya terlihat dari nilai probabilitas tiap item seperti pada Tabel 4 di bawah ini. 
Tabel 4.

Hasil Analisis DIF Aitem

\begin{tabular}{|c|c|c|}
\hline Person classes & Prob & Item \\
\hline 2 & 0,677 & I1 \\
\hline 2 & 0,866 & 12 \\
\hline 2 & 0,797 & 13 \\
\hline 2 & 0,597 & 14 \\
\hline 2 & 0,705 & 15 \\
\hline 2 & 0,086 & 16 \\
\hline 2 & 0,281 & 17 \\
\hline 2 & 0,261 & 18 \\
\hline 2 & 0,130 & 19 \\
\hline 2 & 0,033 & 110 \\
\hline 2 & 0,733 & 111 \\
\hline 2 & 0,524 & 112 \\
\hline 2 & 1,000 & 113 \\
\hline 2 & 0,589 & 114 \\
\hline 2 & 0,541 & 115 \\
\hline 2 & 0,399 & 116 \\
\hline 2 & 0,209 & 117 \\
\hline 2 & 1,000 & 118 \\
\hline 2 & 0,087 & 119 \\
\hline 2 & 0,703 & 120 \\
\hline 2 & 0,274 & 121 \\
\hline 2 & 0,117 & 122 \\
\hline 2 & 0,896 & 123 \\
\hline 2 & 0,540 & 124 \\
\hline 2 & 0,112 & 125 \\
\hline 2 & 0,117 & 126 \\
\hline 2 & 0,713 & 127 \\
\hline 2 & 0,043 & 128 \\
\hline
\end{tabular}

Item-item yang memiliki nilai probabilitas di bawah 0,05 maka menunjukan adanya bias (Sumintono \& Widhiarso, 2014). Berdasarkan tabel tersebut, terlihat item need of agression yang mengandung DIF adalah item 10 dengan nilai probabilitas 0,03 dan item 28 dengan nilai probabilitas 0,04 . Hasil analisis terlihat pula pada Gambar 2 menyatakan bahwa item 10 dan 28 terdeteksi DIF. Hal ini menunjukkan bahwa pada item 10 dan 28 subjek laki-laki dan perempuan memberikan respon yang berbeda. 


\section{Gambar 2.}

DIF Plot

ITEM

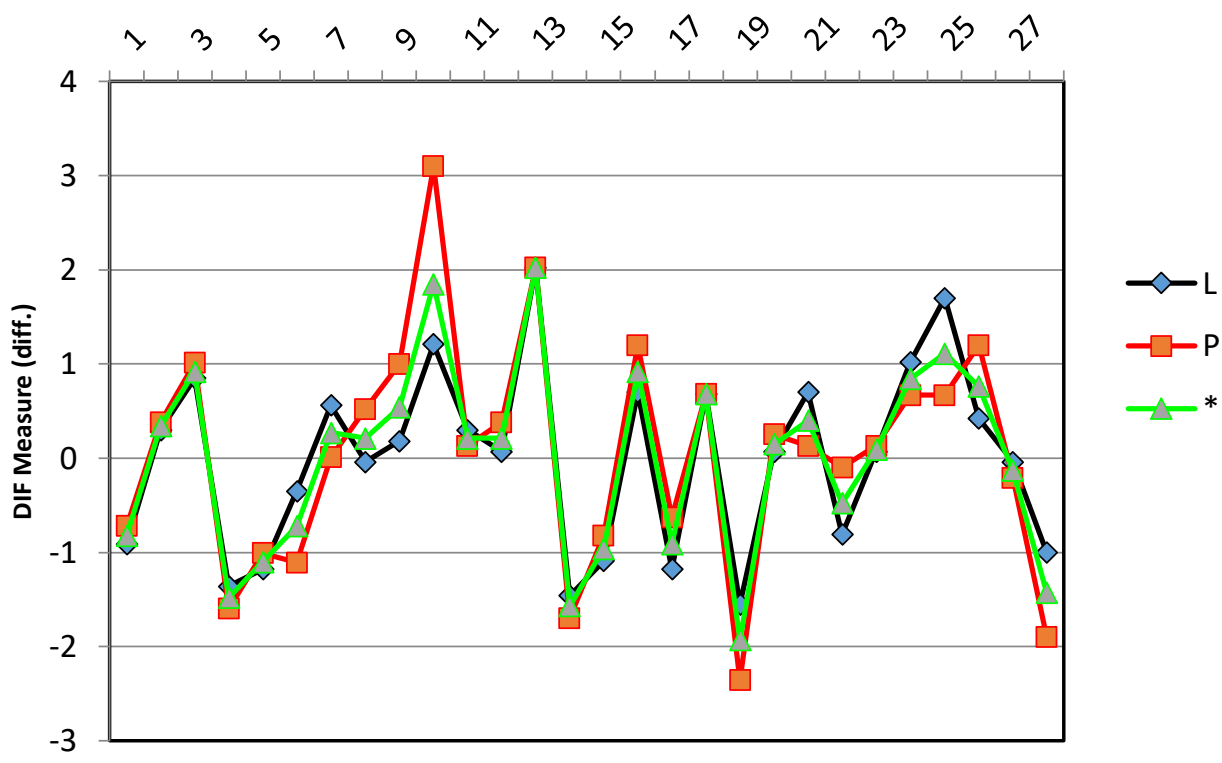

\section{Diskusi}

Berdasarkan analisis data yang telah dilakukan, reliabilitas pada item-item need of agression tergolong baik. Hal ini dilihat dari nilai Alpha Cronbach yaitu sebesar 0,71, kemudian nilai koefisien reliabilitas item senilai 0,93, dan nilai koefisien reliabilitas pada subjek sebesar 0,67. Berkaitan dengan validitas masing-masing item dapat dilihat dari nilai MNSO dan ZSTD, semua item need of agression memenuhi kriteria. Secara umum, item-item need of agression dikatakan bisa mengukur agresi pada subjek jika dilihat dari validitas dan reliabilitasnya. Meskipun analisis validitas dan reliabilitas tes EPPS ini tidak secara keseluruhan, namun hasil analisis validitas dan reliabilitas pada item need of aggression ini menunjukkan bahwa meskipun item ini sudah dibuat lama, tetapi sampai saat ini validitas dan realibiltasnya masih baik.

Terdapat satu item yang paling sulit untuk disetujui oleh subjek, beradasarkan nilai item measure. Item tersebut adalah item 13 yang berbunyi "Saya rasanya ingin menghardik orang-orang lain bila saya berbeda pendapat dengan mereka". Ada sebanyak 6 orang yang setuju dengan item 13 , ini menunjukkan bahwa tidak banyak yang menyetujui item tersebut dikarenakan budaya di Indonesia (terutama Jawa) yang mencerminkan pribadi santun, rendah diri, dan memiliki tutur kata yang halus. Sementara itu item yang paling mudah untuk disetujui oleh subjek adalah item 19 dengan pernyataan "Saya menjadi sedemikian marahnya sehingga rasanya ingin melemparkan dan merusak barangbarang". Pada item 19 ini ada sebesar 68 orang yang setuju, hal ini sejalan dengan karakteristik remaja yang masih mengalami pencarian jati diri sehingga seringkali terjadi gejolak akibat perubahan fisik 
dan psikologisnya (Santrock, 2011) yang berakibat pada perilaku agresif remaja seperti yang tergambar di item 19.

Penelitian sebelumnya yang dilakukan oleh Siregar (2021) menemukan bahwa ada satu item pada kebutuhan heteroseksual yang mengandung DIF berdasarkan jenis kelamin. Pada penelitian ini, terdapat dua item yang terdeteksi bias dalam item-item need of aggression adalah item 10 dengan pernyataan "Saya rasanya ingin menghardik orang lain bila saya berbeda pendapat dengan mereka" dan item nomor 28 dengan pernyataan "Saya rasanya ingin memperolok orang-orang yang melakukan hal-hal yang saya anggap bodoh". Hal ini sesuai dengan hasil penelitian bahwa agresi pada laki-laki cenderung pada fisik dan verbal. Sementara agresi pada perempuan lebih mengarah pada agresi relasional (Dwiyono, 2008). Jika dikaitkan dengan pernyataan pada item yang bias ada perbedaan cara merespon pada laki-laki dan perempuan. Pada item 10 lebih banyak disetujui oleh laki-laki sedangkan item 28 lebih banyak disetujui oleh perempuan.

\section{Kesimpulan}

Berdasarkan hasil penelitian yang telah dilakukan, didapatkan kesimpulan bahwa kualitas item need of agression pada tes EPPS dikatakan baik dan keseluruhan item need of agression dapat diterima oleh subjek, terlihat dari nilai koefisien validitas dan reliabilitasnya. Ini menunjukkan bahwa meskipun item need of aggression sudah dibuat dan digunakan sejak lama, tetapi masih bisa digunakan untuk mengukur agresi seseorang sampai saat ini. Selain itu, diantara item-item yang mengukur need of agression, item yang paling sulit disetujui oleh subjek yaitu item nomor 13. Hal ini dipengaruhi oleh budaya yang ada di Indonesia. Sedangkan item yang paling disetujui oleh subjek adalah item nomor 19 , di mana item ini sesuai dengan karakteristik remaja yang sedang mencari jati diri. Pada item need of agression terdapat bias berdasarkan jenis kelamin, yaitu item 10 lebih banyak disetujui laki-laki dan item 28 yang lebih banyak disetujui oleh perempuan.

\section{Referensi}

Adisubroto, D., Hadipranata, A. F., \& Sudardjo. (1980). Penelitian reliabilitas dan validitas tes EPPS yang di adaptasi. Yogyakarta: Fakultas Psikologi Universitas Gadjah Mada.

Anastasi, A., \& Urbina, S. (2007). (2007). Psychological testing (7th ed.). PT. Indeks. Jakarta: PT. Indeks.

Azwar, S. (2008). Penyusunan skala psikologi. Yogyakarta: Pustaka Pelajar.

Berk, L. E. (2007). Development through the lifesapan 4th edition. Boston: Pearson.

Coccaro, E. F. (2003). aggression: psychiatric assesment and treatment. New York: Marcel Dekker. Inc.

Crick, N. R., \& Dodge, K. A. (1994). A review and reformulation of social information processing mechanisms in children's social adjustment. Psychological Bulletin, 115, 74-101.

Cronbach, L. J. (1990). Essentials of Psychological testing (Fifth Edition). New York: Harper \& Row, Publishers.

Diahsari, E. Y. (2016). Tes kepribadian non proyektif: teori, praktik dan aplikasi. Yogyakarta: Semesta IImu.

Dwiyono, F. (2008). Kecenderungan perperilaku agresif ditinjau dari identitas gender. Yogyakarta: Fakultas Psikologi Universitas Sanata Dharma. 
Edward, A. L. (1959). Edwards personal preference schedule. Manual Revise. US: University of Washington.

Faizah. (2008). Buku panduan mata kuliah tes inventory. Malang: Fakultas Psikologi UIN Maulana Malik Ibrahim Malang.

Fisher Jr., W. P. (2007). Rating scale instrument quality criteria. Rasch Measurement Transaction, 21, 1095.

Ghei, S. N. (1963). The reliability and validity of edwards personal preference schedule: a crosscultural study. The Journal of Social Psychology, 61:2, 241-246, DOI: 10.1080/00224545.1963.9919481.

Gregory, R. J. (2010). Tes psikologi: sejarah, prinsip dan aplikasi (Edisi Keenam, Jilid 2). Jakarta: Penerbit Erlangga.

Hayani, I. M., \& Wulandari, P. Y. (2017). Perbedaan kecenderungan perilaku agresi ditinjau dari harga diri pada mahasiswa. Jurnal Psikologi Pendidikan dan Perkembangan, Vol. 6, pp. 32-42.

Kaplan, R. M., \& Saccuzzo, D. P. (2005). Psychological Testing Principles, Application and Issue. Sixth Edition. USA: Wadsworth.

Osterlind, S. J. (2010). Modern Measurement: Theory, Principles, and Applications of Mental Appraisal (Second Edition). United States of America: Pearson Education, Inc.

Piedmont, R. L., McCrae, R. R., \& Costa, P. T. (1992). An assessment of the edwards personal preference schedule fron the pespective of five factor model. Journal of Personality Assessment, 58(1), 67-78.

Pratomo, L. B. H. (2005). tingkat social desirability item-item EPPS edwards personal preference schedule (Skripsi). Yogkatarta: Fakultas Psikologi Universitas Sanata Dharma

Rosadi, R. S., Widyastuti, \& Rifdah, A. (2018). penyusunan norma edward personal preference schedule (EPPS). Makassar: Repository Universitas Negeri Makassar.

Santrock, J. (2011). life span development: perkembangan masa hidup, Jilid 1 (edisi ketigabelas). Jakarta: Penerbit Erlangga.

Siregar, R. M. (2021). Analisis keberfungsian aitem heteroseksual edwards personal preference schedule (EPPS) pada remaja (Skripsi). Medan: Fakultas Psikologi Universitas Negeri Sumatera Utara.

Soehardi. (2002). Nilai-nilai tradisi lisan dalam budaya jawa. Jurnal Humaniora, Vol. 14, No. 3, hal 1-13. ISSN: 2302-9269

Suhendri, D., \& Rahmawati, E. (2014). Analisis karakteristik psikometri edwards personal preference schedule (EPPS) (Skripsi). Medan: Fakultas Psikologi Universitas Sumatera Utara

Sumintono, B., \& Widhiarso, W. (2014). Aplikasi model rasch untuk penelitian ilmu-ilmu sosial. Cimahi: TrimKom Publishing house.

Thomas J. Bouchard, J. (1968). Convergent and discriminant validity of the adjective check list and edwards personal preference schedule. Educational and Psychological Measurement, 28, 1165-1171.

Yudiati, E. A., \& Rahayu, E. (2018). Analisis kebutuhan dan profil kepribadian pada orang-orang pengidap hiv/aids: tinjauan dari edward personality preference schedule. Psikodimensia, Vol. 17, No. 1, ISSN : 1411-6073, 43-53.

Psikoislamika: Jurnal Psikologi dan Psikologi Islam 
This page is intentionally left blank 